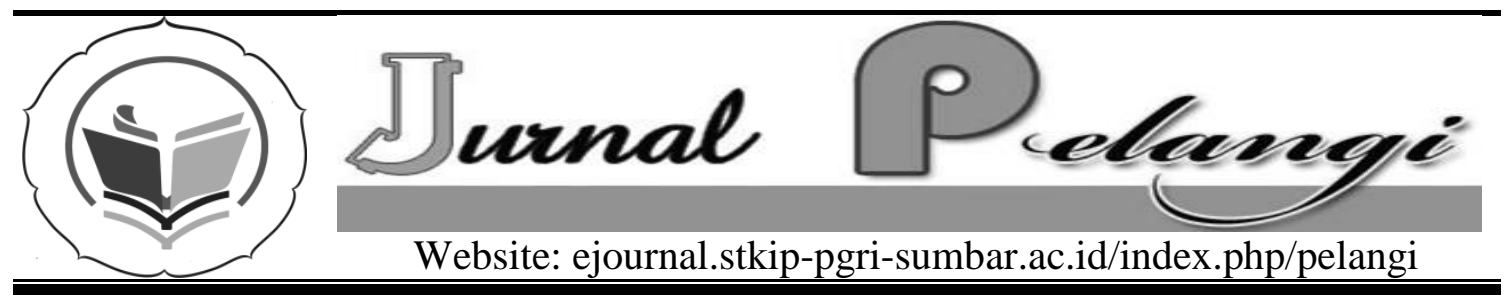

\title{
PENINGKATAN HASIL BELAJAR IPA DENGAN PENDEKATAN CONTEXTUAL TEACHING AND LEARNING
}

\author{
Rosita \\ SD Negeri 16 Kampung Parit Kecamatan Ampek Nagari Kab. Agam \\ rosita@yahoo.com
}

\section{INFO ARTIKEL}

\section{Diterima:}

1 Desember 2015

Direview:

12 Desember 2015

Disetujui:

22 Desember 2015

Kata Kunci:

Hasil belajar, Contextual Teaching and Learning
Keywords:

Learning outcome, Contextual Teaching and Learning

\begin{abstract}
Abstrak
Penelitian dilatarbelakangi dari kenyataan di Sekolah Dasar bahwa pembelajaran sering didominasi oleh guru sebagai sumber informasi Berdasarkan pengamatan ditemukan hasil belajar siswa rendah. Pendekatan Contextual Teaching and Learning (CTL) digunakan untuk meningkatkan hasil belajar siswa. Tujuan penelitian ini untuk meningkatkan hasil belajar IPA dengan menggunakan pendekatan CTL di kelas V SDN 16 Kampung Parit Kecamatan Ampek Nagari. Jenis penelitian ini adalah Penelitian Tindakan Kelas (classroom action research). Penelitian ini menggunakan empat tahap tindakan, yaitu tahap perencanaan, tindakan, observasi dan refleksi. Sumber data adalah proses pelaksanaan pembelajaran dengan pendekatan CTL dikelas V SD Negeri 16 Kampung Parit Kecamatan Ampek Nagari. Subjek penelitian adalah siswa kelas $V$ yang berjumlah 20 orang. Teknik pengumpulan data yang digunakan adalah observasi, pencatatan lapangan, dan teknik tes. Hasil belajar penelitian menunjukan bahwa ratarata nilai siklus I adalah 50, pada siklua II hasil belajar siswa yaitu 84,75. Setelah dilakukan penelitian terungkap bahwa penggunaan pendekatan CTL dapat meningkatkan hasil belajar IPA pada siswa kelas V SD Negeri 16 Kampung Parit Kecamatan Ampek Nagari Kab. Agam.
\end{abstract}

\section{Abstract}

The background of the research is the fact that the learning is often dominated by the teacher as a source of information. Based on the observation it is found that there is a low learning outcome. The researcher used CTL to improve the student's learning outcome. The purpose of the research is improve the learning outcome of natural science by using the Contextual Teaching and Learning (CTL) at the V Class of Elementary School 16 Kampung Parit Kecamatan Ampek 
Nagari, Agam Regency. Type of the research is classroom action research (CAR). The research consisted of 4 stages, i.e. planning, implementing, observing and reflecting. The source of data was the process of learning implementation of CTL in the $V$ Class of Elementary School 16 Kampung Parit Kecamatan Ampek Nagari, Agam Regency. The subject of the research was the class $V$ students, i.e. 20 students. The technique of collecting the data was observation, field note, and test. The result shows that the average score of first cycle is 50 and in the second cycle is 84,75. After conducting the research, it is found that the Contextual Teaching and Learning (CTL) can improve the learning outcome of V Class students of Elementary School 16 Kampung Parit Kecamatan Ampek Nagari, Agam Regency.

\section{PENDAHULUAN}

Perkembangan Ilmu Pengetahuan dan Teknologi (IPTEK) yang sangat pesat menuntut dunia pendidikan untuk selalu mengadakan peningkatan dalam pembelajaran. Salah satu cara yang dapat dilakukan untuk meningkatkan pembelajaran adalah dengan mengadakan pembaharuan pendekatan yang digunakan dalam pembelajaran.

Pendekatan pembelajaran adalah upaya yang dilakukan untuk membuat siswa terlibat aktif dan berminat dalam mengikuti pembelajaran. Menurut Nano (2003:53) pendekatan pembelajaran pada hakikatnya adalah "suatu usaha untuk mengembangkan keefektifan pembelajaran". Kenyataan menunjukkan bahwa manusia dalam segala hal selalu berusaha mencari efisien kerja dengan jalan memilih dan menggunakan suatu cara yang dianggap terbaik untuk mencapai tujuannya. Demikian juga dengan pembelajaran, guru selalu berusaha memilih pendekatan pembelajaran yang tepat dan dipandang lebih efektif daripada pendekatan lain.
Penggunaan pendekatan dalam pembelajaran berpengaruh terhadap hasil belajar yang diperoleh, semakin tepat pendekatan yang digunakan maka hasil yang diperoleh semakin maksim Begitu pentingnya pendekatan dalam pembelajaran, sehingga guru dituntut mempunyai pengetahuan dan keterampilan dalam memilih dan menerapkan berbagai pendekatan pembelajaran yang sesuai dengan karakteristik siswa dan materi pembelajaran.

Berdasarkan pendapat Maslichah (2006:37) yang menyatakan bahwa "untuk keberhasilan suatu pembelajaran guru perlu mengetahui dengan siapa atau siswa yang bagaimana yang akan dihadapi, tanpa paham tentang siswa yang akan difasilitasi mustahil guru dapat memilih pendekatan pembelajaran yang tepat dan materi pembelajaran yang sesuai".

Tugas guru dalam pembelajaran dengan menggunakan pendekatan Contextual Teaching and Learning (CTL) adalah suatu pendekatan pengajaran yang dari karaktristiknya dapat memenuhi harapan para ahli 
pendidikan dan pengajar dalam upaya menghidupkan kelas secara alami dalam bentuk kegiatan siswa berkerja, dan mengalami, bukan transfer pengetahuan dari guru ke siswa. Sebagaimana pendapat Gagne (dalam Wahyudin, 2008:1) menyatakan bahwa "hasil belajar adalah kemampuan yang diperoleh seseorang sesudah mengikuti proses belajar". Hasil belajar siswa dikatakan baik apabila ranah kognitif, afektif, dan psikomotor meningkat. Meningkatnya ketiga aspek ini dapat diamati langsung dalam pembelajaran Ilmu Pengetahuan Alam (IPA), karena aspek pokok dalam pembelajaran IPA menurut Usman (2006:12) adalah "membangkitkan rasa ingin tahu siswa untuk menggali berbagai pengetahuan baru, dan akhirnya dapat mengaplikasikan dalam kehidupan mereka".

Di Sekolah Dasar pembelajaran IPA terdiri dari empat aspek yakni: makhluk hidup dan proses kehidupannya, benda/materi, sifat dan kegunaannya, energi dan perubahannya, serta bumi dan alam semesta. Keempat aspek ini merupakan fokus tujuan pembelajaran IPA di SD. Menurut Depdiknas (2006: 484) pembelajaran IPA bertujuan untuk "menumbuhkan kemampuan berfikir, bekerja dan bersikap ilmiah, serta mengkomunikasikannya sebagai aspek penting kecakapan hidup".

Pada saat ini kemampuan siswa SD untuk menerapkan IPA di lingkungannya sehari-hari tergolong rendah. Untuk meningkatkan kemampuan tersebut, ada beberapa aspek yang dapat diperhatikan guru dalam pembelajaran IPA yang dikemukakan oleh Usman (2006:5) antara lain: (1) pentingnya memahami bahwa pada saat memulai kegiatan pembelajaran IPA, siswa telah memiliki berbagai konsepsi, pengetahuan yang relevan dengan apa yang mereka pelajari, (2) aktivitas siswa melalui berbagai kegiatan nyata dengan alam menjadi hal utama dalam pembelajaran IPA, (3) bertanya merupakan ciri utama dalam pembelajaran IPA dan memiliki peran penting dalam upaya membangun pengetahuan selama pembelajaran, (4) pembelajaran IPA memberikan kesempatan kepada siswa untuk mengembangkan kemampuan berpikir dalam menjelaskan suatu masalah.

Salah satu pendekatan yang dapat digunakan untuk meningkatkan hasil belajar adalah pendekatan Contextual Teaching and Learning (CTL). Berdasarkan pendapat di atas, maka pendekatan Contextual Teaching and Learning (CTL) merupakan salah satu pendekatan yang dapat digunakan dalam pembelajaran IPA, karena proses pembelajaran dengan pendekatan kontruktivisme merupakan proses mengasimilasi dan menghubungkan pengalaman atau bahan yang dipelajari dengan pengertian yang sudah dipunyai siswa. Proses tersebut menurut Cox (dalam Ritawati, 2001:15) diantaranya bercirikan "hasil belajar dipengaruhi oleh pengalaman siswa dengan dunia fisik dan lingkungannya, hasil belajar tergantung pada apa yang telah diketahui siswa tentang konsep-konsep, tujuan, dan motivasi yang mempengaruhi interaksi dengan bahan yang dipelajari”. Jadi dengan penerapan pendekatan kontruktivisme dalam pembelajaran IPA 
dapat mempengaruhi hasil belajar yang diperoleh siswa, karena siswa mempunyai cara sendiri untuk mengerti tentang apa yang mereka pelajari.

Pengalaman penulis selama menjadi guru khususnya dalam pembelajaran IPA di kelas V SDN 16 Kampung Parit Kecamatan Ampek Nagari, guru belum sepenuhnya melibatkan siswa secara aktif. Hal ini disebabkan keterbatasan alat peraga dan kurangnya variasi penerapan metode maupun pendekatan pembelajaran, guru cenderung menggunakan pendekatan konvensional adalah pendekatan penbelajaran dimana guru yang selalu menjelaskan di depan kelas (ceramah). Siswa dalam pembelajaran belum dijadikan subjek belajar, kebanyakan siswa menerima materi yang disampaikan guru berupa hafalan. Hal ini menyebabkan rendahnya hasil belajar yang diperoleh siswa, adapun nilai rata-rata hasil belajar IPA ulangan harian dengan pendekatan dan metode ceramah yang digunakan nilai rata-rata siswa rendah dibawah nilai KKM. Nilai KKM yang ditetapkan sekolah untuk mata pelajaran IPA di kelas V adalah 60

\section{METODE PENELITIAN}

Penelitian ini adalah penelitian tindakan kelas pada siswa kelas V SD yang meliputi perencanaan pembelajaran dan pelaksanaan pembelajaran serta evaluasi pembelajaran. Data diperoleh dari subjek, yakni siswa kelas V SD Negeri 16 Kampung Parit Kecamatan Ampek Nagari.

\section{HASIL DAN PEMBAHASAN}

Pada siklus I dilakukan pengamatan oleh teman sejawat pada guru dan siswa yang sedang melaksanakan proses pembelajaran. Guru sudah melaksanakan pembelajaran IPA namun siswa belum aktif mengikutinya. Pada saat pembelajaran berlangsung pun siswa kurang aktif untuk bertanya, mengajukan pertanyaan serta menanggapinya.

Pada akhir pembelajaran guru menjelaskan pelajaran yang menyangkut tema yang dipelajari, serta memberi contoh cara menjawab, mengajukan pertanyaan serta menanggapinya. Siswa mendengarkan penjelasan guru dengan senang dan penuh semangat. Selanjutnya guru memberikan tugas rumah dan menyampaikan pembelajaran untuk siklus II.

Pada siklus II, proses pembelajaran IPA masih dilakukan pengamatan oleh teman sejawat. Hasil pengamatan menunjukkan pembelajaran berlangsung dengan baik, siswa pun lebih aktif dan bersemangat pada saat masing-masing siswa disuruh membaca teks bacaan ke depan kelas.

Pada saat masing-masing siswa disuruh ke depan kelas siswa lebih aktif dan lebih bersemangat lagi dan dalam membaca hasil diskusi kelompok. Selama proses pembelajaran sudah banyak siswa yang bertanya, yang mengajukan pertanyaan dan bahkan ada yang menanggapinya. Pada siklus II ini banyak sekali perubahan dan penigkatan yang signitif dari proses pengajaran guru dan proses pembelajaran dari siswa sehingga dapat dilihat nilai persentasi dari ketuntasan anak yang mencapai 
$84.75 \%$, sedangkan pada siklus I persentasi ketuntasan anak hanya mencapai $50 \%$.

\section{PENUTUP}

Proses pembelajaran IPA dengan menggunakan pendekatan CTL dapat meningkatkan hasil belajar siswa khususnya kelas V SD 16 Kampung Parit yang berfokus pada penguasaan materi oleh siswa secara tepat meskipun harus dilakukan secara terus menerus. Dalam proses pembelajaran sangat berpengaruh untuk meningkatkan keaktifan siswa dalam belajar.

Pengalaman peneliti membuktikan terjadinya perbaikan dan peningkatan keberhasilan dalam proses pembelajaran dapat dilihat dari persentase ketuntasan belajar anak yang mencapai $84.75 \%$. Juga meningkatnya kemampuan dan penguasaan materi oleh siswa, serta meningkatkan semangat mengajar guru dalam menghadapi masalah-masalah yang timbul dalam proses pembelajaran.

Berdasarkan hasil penelitian dan pembahasan serta kesimpulan yang diperoleh, dapat dikemukakan sasaran sebagai berikut:

1. Agar rencana pelaksanaan pembelajaran bagus maka guru perlu lebih kreatif dalam merancang pembelajaran yang sesuai dengan situasi dunia nyata, memperhatikan sumber materi ajar, dan sesuai dengan karakteristik siswa dan lingkungan dimana siswa tinggal.

2. Dalam pelaksanaan pembelajaran disarankan agar dalam memberikan materi disesuaikan dengan konteks sehari-hari siswa, perlu memberikan perhatian, bimbingan dan motivasi belajar secara sungguh-sungguh kepada siswa yang berkemampuan kurang pasif dalam kelompok, karena siswa yang demikian sering menggantungkan diri pada temannya.

3. Agar hasil belajar yang diharapkan dapat meningkat, sebaiknya guru tidak hanya melakukan penilaian hasil saja, tetapi juga melakukan penilaian proses untuk melihat keaktifan dan kemampuan siswa dalam menemukan jawaban dari suatu permasalahan yang sudah dirumuskan.

\section{UCAPAN TERIMA KASIH}

Terbitnya tulisan ini tidak terlepas dari bantuan berbagai pihak, untuk itu penulis ucapkan terima kasih yang sebesar-basarnya kepada Pihak STKIP PGRI Sumatera Barat khususnya pengelola jurnal Pelangi yang telah memberikan kesempatan kepada penulis untuk menulis di jurnal Pelangi. Selanjutnya penulis juga berterima kasih kepada para penyumbang sumber insirasi yang telah memerikan inspirasi bagi penulis untuk mengutip atau menggunakan tulisannya sebagai bahan referensi.

\section{DAFTAR PUSTAKA}

Chaedar Alwasilah. 2007. Contextual Teaching dan Learning. Bandung. MLC.

Desy Anwar. 2003. Kamus Lengkap Bahasa Indonesia. Surabayo. AMELIA

Dr.E. Mulyasa, M.Pd. 2009. Menjadi Guru Profesional Menciptakan Pembelajaran Kreatif dan Menyenangkan. Bandung. Remaja Rosdakarya 
Hendri, Wince. 2007. Bahan Ajar Pembelajaran IPA SD. Padang PGSD UBH.

IGAK Wardhani dan Kuswaya Wihardit. 2009. Penelitian Tindakan Kelas. Jakarta. Universitas Terbuka.

Iqbal Hasan. 2008. Analisis Data Penelitian dengan Statistik. Jakarta. PT Bumi Aksara

Masnur muslich. 2009. KTSP Dasar Pemahaman dan Pengembangan. Jakarta. Bumi Aksara

Noehi, Nasution dkk. 2004. Pendidikan IPA di SD 1-6. Jakarta: Universitas Terbuka

Oemar Hamalik. 2001. Proses Belajar Mengajar. Jakarta: Bumi Aksara
Rochiati Wiriaatmadja. 2010. Metode penelitian tindakan kelas. Bandung. PT Remaja Rosdakarya

S. Margono. 2003. Metodologi Penelitian Pendidikan. Jakarta. Reneka cipta.

Sardiman. 2011. Interaksi dan motivasi belajar mengajar. Jakarta. Rajawali Pers

Sudjana, 2001 Metode \& Teknik Pembelajaran Partisipatif. Cet. IV. Bandung: Falah Production

Suharsimi Arikunto. 2008. Proses Penelitian Suatu Pendekatan Pratik. Jakarta. PT Asdi Mahasatya

Wina Sanjaya. 2009. Strategi Pembelajaran Berorientasi Standar Proses Pendidikan. Jakarta. Kencana Prenada Media Group. 